\title{
Pengaruh Diabetes Mellitus Terhadap Kejadian Disfungsi Ereksi
}

\author{
Alpacino J. Wowor, ${ }^{1}$ Lydia E. N. Tendean, ${ }^{2}$ Janette M. Rumbajan ${ }^{2}$
}

\author{
${ }^{1}$ Program Studi Pendidikan Dokter Fakultas Kedokteran Universitas Sam Ratulangi, \\ Manado, Indonesia \\ ${ }^{2}$ Bagian Biologi Fakultas Kedokteran Universitas Sam Ratulangi, Manado, Indonesia \\ Email: alpacinojeremy123@gmail.com
}

\begin{abstract}
Diabetes Mellitus (DM) is a non-communicable disease that can be found at all ages, especially in adults and the elderly. Erectile Dysfunction (ED) is the inability to maintain an erection. Like DM, DE is still a problem facing the world, including Indonesia. Blood vessels can be damaged by various factors, one of which is uncontrolled blood sugar levels that can lead to Erectile Dysfunction. The International Index of Erectile Function (IIEF-5) or Sexual Health Inventory for Men (SHIM) is a tool for diagnosing ED. The purpose of this study was to determine the effect of Diabetes Mellitus on the incidence of Erectile Dysfunction. This study took the form of a literature review with data searches using three databases, namely Pubmed, ScienceDirect and Google Scholar. The keywords used were Diabetes Mellitus "AND" Erectile Dysfunction. 10 literature was obtained after being selected based on inclusion and exclusion criteria. According to the ten literature selected in this study, all found an effect of Diabetes Mellitus on the incidence of Erectile Dysfunction. In Conclusion, Diabetes Mellitus affects the occurrence of Erectile Dysfunction.
\end{abstract}

Keywords: Diabetes Mellitus, Erectile Dysfunction.

\begin{abstract}
Abstrak: Diabetes Mellitus (DM) merupakan penyakit tidak menular yang dijumpai pada segala usia terutama pada dewasa dan lansia. Disfungsi Ereksi (DE) merupakan ketidakmampuan dalam mempertahankan ereksi. Seperti halnya DM, DE juga masih menjadi masalah yang dihadapi dunia termasuk Indonesia. Pembuluh darah dapat mengalami kerusakan oleh berbagai faktor, salah satunya adalah kadar gula darah yang tidak terkontrol sehingga dapat memicu terjadinya Disfungsi Ereksi. International Index of Erectile Function (IIEF-5) atau Sexual Health Inventory for Men (SHIM) merupakan alat bantu dalam penegakan diagnosis DE. Tujuan penelitian ini adalah untuk mengetahui pengaruh Diabetes Mellitus terhadap kejadian Disfungsi Ereksi. Penelitian ini berbentuk literature review dengan pencarian data menggunakan tiga database, yaitu Pubmed, ScienceDirect dan Google Cendekia. Kata kunci yang digunakan yaitu Diabetes Mellitus "DAN" Erectile Dysfunction. Didapatkan 10 literatur setelah diseleksi berdasarkan kriteria inklusi dan eksklusi. Berdasarkan dari sepuluh literatur yang dipilih dalam penelitian ini, seluruhnya mendapati adanya pengaruh Diabetes Mellitus terhadap kejadian Disfungsi Ereksi. Sebagai simpulan, Diabetes Mellitus berpengaruh terhadap terjadinya Disfungsi Ereksi.
\end{abstract}

Kata kunci: Diabetes Mellitus, Disfungsi Ereksi.

\section{PENDAHULUAN}

Diabetes Mellitus (DM) merupakan penyakit tidak menular yang dijumpai pada segala usia terutama pada dewasa dan lansia. Berdasarkan hasil Riset Kesehatan Dasar (RISKESDAS) tahun 2018 menunjukkan prevalensi Diabetes Mellitus di Indonesia sebesar 1,5\%. Kelompok usia dengan prevalensi tertinggi yakni 55-64 tahun sebesar 6,3\%. Sedangkan berdasarkan jenis kelamin, perempuan memiliki prevalensi tertinggi dibandingkan laki-laki, yakni 1,8\%. ${ }^{1}$

Diabetes Mellitus dapat disebabkan oleh autoimun, genetik, obesitas, dan etnis. ${ }^{2}$ Kadar gula darah yang tidak terkontrol 
pada DM dapat memicu terjadinya kerusakan pembuluh darah. Endotel dalam keadaan normal dapat menghasilkan nitrit oksida (NO) yang berguna dalam melebarkan pembuluh darah, termasuk pembuluh darah di penis. ${ }^{3}$ Kadar gula yang tinggi diakibatkan oleh sedikitnya insulin yang disekresikan, sehingga memicu enzim arginase II disekresikan secara berlebihan di korpus kavernosum yang mengakibatkan terjadinya penghambatan aktivitas NO yang diperlukan dalam kontraktilitas otot polos pembuluh darah. Akibatnya, pembuluh darah penis sulit melebar dan aliran darah ke organ erektil menurun sehingga dapat memicu terjadinya Disfungsi Ereksi. ${ }^{8}$

Disfungsi Ereksi (DE) atau ketidakmampuan mempertahankan ereksi seringkali dialami oleh pria karena berbagai faktor. Massachusetts Male Aging Study (MMAS) melaporkan prevalensi Disfungsi Ereksi sedang adalah 34\% dan parah adalah $15 \%$ dengan masing-masing usia antara 40 dan 70 tahun. ${ }^{4}$ International Index of Erectile Function (IIEF-5) atau Sexual Health Inventory for Men (SHIM) merupakan alat bantu dalam penegakan diagnosis Disfungsi Ereksi yang terdiri dari 5 pertanyaan yang masing-masing diberi skor $1-5.5$

Oleh karena Diabetes Mellitus dapat menjadi masalah serius pada individu yang mengalami kejadian Disfungsi Ereksi, maka peneliti tertarik untuk meneliti pengaruh Diabetes Mellitus terhadap kejadian Disfungsi Ereksi.

\section{METODE PENELITIAN}

Penelitian ini dilaksanakan pada bulan September-Desember 2020 di perpustakaan virtual. Jenis penelitian ini adalah studi literatur (literature review). Populasi dalam penelitian ini yaitu artikel dan dokumen terbitan 10 tahun terakhir yang diperoleh dari database Pubmed, ScienceDirect, dan Google Scholar. Teknik yang digunakan untuk mengumpulkan data penelitian berupa pengumpulan data kepustakaan yang berkesinambungan dengan topik pembahasan tentang pengaruh Diabetes
Mellitus terhadap kejadian Disfungsi Ereksi. Pencarian data menggunakan kata kunci Diabetes Mellitus "DAN" Disfungsi Ereksi, baik dalam Bahasa Indonesia maupun Bahasa Inggris. Pada penelitian ini, jurnal yang telah memenuhi kriteria inklusi dan eklusi berjumlah 10 jurnal.

\section{HASIL PENELITIAN}

Sepuluh literatur memenuhi kriteria inklusi dan eksklusi yang telah ditentukan menjadi sumber data dalam penelitian ini. Enam literatur membahas secara langsung topik Diabetes Mellitus dan Disfungsi Ereksi, tiga literatur membahas topik Disfungsi Ereksi dan topik yang berkaitan dengan Diabetes Mellitus, serta satu literatur membahas topik Diabetes Mellitus dan topik yang berkaitan dengan Disfungsi Ereksi. Sebanyak tiga literatur menggunakan analisis data Pearson, dua literatur menggunakan analisis data chisquare, dua literatur lainnya menggunakan analisis data regresi logistik biner, serta tiga literatur lainnya menggunakan analisis data Spearman, analisis univariat, dan analisis multivariat linear. Tiga literatur merupakan penelitian yang dilakukan di negara Italia. Sedangkan tujuh literatur lainnya merupakan penelitian yang dilakukan di Indonesia, Jerman, Iran, Republik Ceko, India, Turki, dan Sri Lanka. Tabel 1 memperlihatkan karakteristik keempat jurnal yang dipakai dalam penelitian ini.

\section{BAHASAN}

Penelitian tahun 2019 menemukan adanya hubungan antara lama kejadian DM dengan kejadian DE pada lansia. Hasil uji Chi-Square diperoleh nilai $\mathrm{p}=0,000$ lebih kecil dari nilai $\alpha=0,005$. $^{6}$ Laporan lain tahun 2020 pada 720 pria penderita Diabetes Mellitus tipe 2 menunjukkan subjek dengan DE memiliki durasi DM yang lebih lama $(8.1 \pm 4,9$ tahun $)$ dibandingkan yang tidak DE $(4,4 \pm 3,5$ tahun) $(\mathrm{p}<0,05) .{ }^{11}$ Hal ini terjadi karena konsentrasi plasma dan kandungan vaskular L-arginin, substrat yang memberikan kofaktor NADPH bagi NOS, akan terus berkurang ketika berada dalam 
keadaan kekurangan insulin. Hal ini dapat memicu enzim arginase II, disekresikan secara berlebihan dalam korpus kaver- nosum, sehingga terjadi penghambatan aktivitas NOS yang diperlukan dalam kontraktilitas otot polos pada penis. ${ }^{8}$

Tabel 1. Karakteristik jurnal berdasarkan peneliti, tempat, sampel, analisis data, dan ringkasan hasil

\begin{tabular}{|c|c|c|c|c|c|}
\hline No. & Peneliti & Tempat & Sampel & $\begin{array}{c}\text { Analisis } \\
\text { Data }\end{array}$ & Ringkasan Hasil \\
\hline 1 & $\begin{array}{l}\text { Rini, } \\
2019^{6}\end{array}$ & $\begin{array}{l}\text { Nagas- } \\
\text { widak, } \\
\text { Indonesia }\end{array}$ & $\begin{array}{l}30 \text { pria } \\
\text { penderita } \\
\text { Diabetes } \\
\text { Mellitus }\end{array}$ & $\begin{array}{l}\text { Chi- } \\
\text { Square }\end{array}$ & $\begin{array}{l}\text { Ada hubungan antara lama kejadian DM } \\
\text { dengan kejadian DE pada lansia. Hasil uji Chi- } \\
\text { Square diperoleh nilai } \mathrm{p}=0,000 \text { lebih kecil dari } \\
\text { nilai } \alpha=0,005 \text {. }\end{array}$ \\
\hline 2 & $\begin{array}{l}\text { Yassin, } \\
2015^{7}\end{array}$ & $\begin{array}{l}\text { Braun- } \\
\text { shweigh, } \\
\text { Jerman }\end{array}$ & $\begin{array}{l}130 \text { pria } \\
\text { dengan } \\
\text { Late } \\
\text { Onset } \\
\text { Hypo- } \\
\text { gonadism }\end{array}$ & Pearson & $\begin{array}{l}\text { Ada hubungan yang signifikan antara tingkat } \\
\text { keparahan DE dengan kadar HbA1c }(\mathrm{p}<0,001) \\
\text { dan glukosa puasa }(\mathrm{p}=0,003) \text {. }\end{array}$ \\
\hline
\end{tabular}

3 Derosa, Pavia, 88 pria $2012^{8} \quad$ Italia penderita

Pearson

Prevalensi DE pada pria Italia penderita DM Diabetes tipe 2 dengan usia rata-rata 62 tahun sekitar $56 \%$ dan dikaitkan dengan peningkatan insulin plasma puasa, serta kadar testosteron bebas dan dihidrotestosteron yang lebih rendah.

4 Jazayeri, Shiraz, 42 pria $2014^{9}$ Iran penderita Disfungsi Ereksi Vaskular

Pearson Pasien dengan SSR abnormal mengalami DE yang lebih parah menurut skor IIEF $(p<0,001)$. Selain itu, skor IIEF memiliki korelasi yang signifikan dengan DM dan Penyakit Kardiovaskular $(\mathrm{p}<0,05)$. Pasien DM dalam sampel memiliki tingkat abnormalitas atau ketiadaan SSR yang lebih tinggi yang dicatat dari saraf medianus dan tibialis daripada pasien non-DM.

5 Hylmarova,Praha, 57 pria $2019^{10} \quad$ Republik penderita

Spearman Pasien yang menderita nefropati diabetik memiliki skor IIEF-5 yang lebih rendah daripada pasien tanpa komplikasi nefropati diabetik $(\mathrm{p}=0,008)$.

tipe 1

6 Nutalapati, Belagavi, 720 pria

Regresi logistik $2020^{11} \quad$ India penderita Diabetes Mellitus tipe 2

7 Derosa, Pavia, 220 pria $2015^{12} \quad$ Italia penderita Diabetes Mellitus tipe 2

8 Cander, Bursa, 116 pria $2014^{13} \quad$ Turkey penderita Diabetes

biner

ChiSquare
Pasien dengan DE memiliki kadar trigliserida $(9,9 \mathrm{mU} / \mathrm{ml})$ dan glukosa plasma $(8.2 \mathrm{mU} / \mathrm{ml})$ $(\mathrm{p}<0,05)$ yang lebih tinggi. Kadar resistin lebih tinggi pada pasien dengan DE dibandingkan yang tidak $\mathrm{DE}(\mathrm{p}<0,05)$ dan testosteron bebas lebih rendah pada pasien yang terkena DE.

Analisis Analisis univariat menunjukkan bahwa univariat polineuropati diabetik adalah faktor yang dikaitkan dengan kemungkinan yang lebih 
Mellitus

tipe 2

9 Maiorino, Napoli, $2016^{14} \quad$ Italia

151 pria penderita Diabetes Mellitus tipe 1
Analisis multivariat linear

10 Nisahan, Jaffna, 326 pria $2019^{15}$ Sri Lanka penderita Diabetes Mellitus

Regresi logistik biner tinggi $(93,3 \%$ jika ada dan $60,0 \%$ jika tidak ada neuropati) dan keparahan (43,3\% jika ada dan $14,3 \%$ jika tidak ada neuropati) dari DE $(\mathrm{p}=0,004)$.

Prevalensi DE lebih tinggi pada kelompok yang diberi suntikan multipel harian insulin (MDI) (36\%) dan infus insulin subkutan kontinyu (CSII) (39\%) $(\mathrm{p}=0,326)$. Lebih dari separuh pria diabetes (58\%) mengalami DE ringan. Pria diabetes dengan DE menunjukkan berat badan yang lebih rendah dan indeks massa tubuh, glukosa puasa, dosis insulin, kolesterol, high density lipoprotein (HDL), serta Self-Rating Depression Score (SRDS) yang lebih tinggi.

Analisis bivariat menunjukkan usia di atas 40, durasi DM (>5 tahun), jenis diabetes (tipe 2), komplikasi mikrovaskular, hipertensi, IMT, konsumsi alkohol dan penggunaan betablocker dikaitkan dengan DE ( $\mathrm{P}<0,05)$.
Penelitian tahun 2015 melaporkan adanya hubungan yang signifikan antara tingkat keparahan Disfungsi Ereksi dengan kadar $\mathrm{HbA1c}(\mathrm{p}<0,001)$ dan glukosa puasa $(\mathrm{p}=0,003){ }^{7}$ Demikian juga yang dilakukan di Denpasar, Bali menunjukkan pria yang memiliki kontrol glukosa yang buruk dengan kadar $\mathrm{HbA} 1 \mathrm{c}>7 \%$ dapat 5 kali lebih mungkin terkena DE. HbA1c dapat menggambarkan keadaan kadar glukosa selama 120 hari usia sel darah merah, sehingga dapat dijadikan parameter pengendalian DM. $^{16}$ Juga penelitian di Florence, Italia yang menunjukkan pasien dengan glukosa puasa terganggu lebih sering mengalami DE parah, aliran darah penis berkurang, dan hipogonadisme dibandingkan pasien dengan kadar glukosa normal. ${ }^{17}$ Terdapat juga laporan tentang prevalensi $\mathrm{DE}$ pada pria Italia penderita DM tipe 2 dengan usia rata-rata 62 tahun sekitar $56 \%$ dan dikaitkan dengan peningkatan insulin plasma puasa, serta kadar testosteron bebas dan dihidrotestosteron yang lebih rendah. ${ }^{8}$ Dalam penelitian di Puskesmas Nagaswidak, Indonesia menemukan sebanyak 43,3\% lansia kategori ederly yang menderita DM dan mengalami DE.
Kualitas dari perfusi jaringan dapat dipengaruhi oleh usia melalui peningkatan kadar glukosa darah dan perubahan pembuluh darah. Menurut WHO ketika seseorang mulai mencapai usia 30 tahun, maka kadar glukosa darah puasa akan meningkat $1-2 \mathrm{mg} / \mathrm{dl} / \mathrm{tahun}$ dan pada 2 jam setelah makan akan naik sekitar 5,6-13 mg/dl/tahun. ${ }^{6}$

Pasien dengan SSR abnormal mengalami DE yang lebih parah menurut skor IIEF $(\mathrm{p}<0,001)$. Selain itu, skor IIEF memiliki korelasi yang signifikan dengan DM dan Penyakit Kardiovaskular $(\mathrm{p}<0,05)$. Pasien DM dalam sampel memiliki tingkat abnormalitas atau ketiadaan SSR yang lebih tinggi yang dicatat dari saraf medianus dan tibialis daripada pasien nonDM. ${ }^{9}$ SSR adalah perubahan potensi kulit setelah rangsangan gairah. Hal ini merupakan refleks polisinaps dan jalur eferen yang melibatkan serat sudomotor simpatis pra dan postganglionik dan akhirnya dapat mengaktivasi kelenjar keringat oleh aliran simpatis. SSR di penis (PSSR) dianggap sebagai metode untuk mengevaluasi persarafan simpatik penis. ${ }^{18}$ Juga bahwa kontrol glikemik yang buruk dikaitkan dengan peningkatan keparahan 
status fungsional simpatis pada pasien DM. $^{19}$

Pasien yang menderita nefropati diabetik memiliki skor IIEF-5 yang lebih rendah daripada pasien tanpa komplikasi nefropati diabetik $(p=0,008) .{ }^{10}$ Laporan penelitian yang dilakukan pada 30 pasien yang dibawa ke unit hemodialisis di rumah sakit Charles Nicolle Tunis, Tunisia menyatakan prevalensi DE pada pasienpasien tersebut adalah $80 \%$, termasuk $33,3 \%$ mengalami DE parah. $^{20}$

Pasien dengan DE memiliki kadar trigliserida $(9,9 \mathrm{mU} / \mathrm{ml})$ dan glukosa plasma $(8.2 \mathrm{mU} / \mathrm{ml})(\mathrm{p}<0,05)$ yang lebih tinggi. Kadar resistin lebih tinggi pada pasien dengan DE dibandingkan yang tidak DE $(p<0,05)$ dan testosteron bebas lebih rendah pada pasien yang terkena $\mathrm{DE} .^{12}$ Sementara pada penelitian di Napoli, Italia pada 151 pria penderita Diabetes Mellitus tipe 1 menunjukkan prevalensi DE lebih tinggi pada kelompok yang diberi suntikan multipel harian insulin (MDI) $(36 \%)$ dan infus insulin subkutan kontinyu (CSII) $(39 \%)(\mathrm{p}=0,326)$. Lebih dari separuh pria diabetes $(58 \%)$ mengalami DE ringan. Pria diabetes dengan DE menunjukkan berat badan yang lebih rendah dan indeks massa tubuh, glukosa puasa, dosis insulin, kadar kolesterol, high density lipoprotein (HDL), serta Self-Rating Depression Score (SRDS) yang lebih tinggi. ${ }^{14}$

Pada pria obesitas terjadi penurunan adiponektin tetapi mengalami peningkatan resistin dan Retinol Binding Protein-4 (RBP-4), hal ini yang mengakibatkan terbentuknya sel lemak yang berpengaruh terhadap hormon testosteron. Pada pria yang obesitas terdapat lebih banyak sel lemak di dalam tubuhnya. Sel lemak ini melepaskan enzim aromatase yang memfasilitasi perubahan testosteron menjadi estradiol. Aromatisasi dominan terjadi di jaringan perifer dari pada testis. Testosteron dalam jumlah tertentu dikonversikan menjadi estradiol, dehidrotestosteron dan etiokolanolon dalam batas normal. Testosteron mengalami aromatisasi menjadi estrogen pada pria yang mempunyai lemak berlebihan dalam tubuh pria normal. Perbandingan normal testosteron dan estradiol adalah 50:1. Semakin bertambah berat badan, maka semakin cepat perubahan hormon testosteron menjadi estradiol. ${ }^{21}$

Namun ada juga laporan mengungkapkan bahwa tidak ditemukan hubungan antara komponen Sindrom Metabolik dengan terjadinya DE walaupun dapat meningkatkan risiko 0,913 kali terkena DE bila dibandingkan dengan individu yang tidak mengalami Sindrom Metabolik. ${ }^{22}$ Laporan lainnya menyatakan analisis bivariatnya menunjukkan usia di atas 40, durasi DM ( $>5$ tahun), jenis diabetes (tipe 2), komplikasi mikrovaskular, hipertensi, IMT, konsumsi alkohol dan penggunaan beta-blocker dikaitkan dengan $\mathrm{DE}(\mathrm{P}<0,05) .{ }^{15}$

Polineuropati diabetik adalah faktor yang dikaitkan dengan kemungkinan yang lebih tinggi (93,3\% jika ada dan $60,0 \%$ jika tidak ada neuropati) dan keparahan $(43,3 \%$ jika ada dan 14,3\% jika tidak ada neuropati) dari $\operatorname{DE}(p=0,004) .{ }^{13}$ Hal ini juga yang diungkapkan dalam penelitian di Pusat Diabetes Rumah Sakit Universitas Manchester Pusat, Inggris yang menyatakan neuropati serat kecil pada pria dengan DM berhubungan dengan DE. Ini terutama dimediasi oleh kecacatan sinyal saraf non-adrenergik, non-kolinergik, disfungsi endotel penis dan penyakit venooklusif sehingga menimbulkan gangguan vasodilatasi korpus kavernosum. ${ }^{4}$

\section{SIMPULAN}

Diabetes Mellitus berpengaruh terhadap terjadinya Disfungsi Ereksi.

\section{Konflik Kepentingan}

Penulis menyatakan tidak terdapat konflik kepentingan dalam studi ini.

\section{DAFTAR PUSTAKA}

1. Riset Kesehatan Dasar (Riskesdas) (2018). Badan Penelitian dan Pengembangan Kesehatan Kementerian RI tahun 2018. 2018.

2. Kliegman RM. Nelson Textbook of Pediatrics. 21st ed. Philadelphia: 
Elsevier Inc.: 2020.

3. Soelistijo SA, Dkk. Pengelolaan dan pencegahan diabetes melitus tipe 2 di indonesia 2015. PB PERKENI; 2015.

4. Feldman HA, Goldstein I, Hatzichristou DG. Impotence and its medical and psychosocial correlates: results of the Massachusetts Male Aging Study. J Urol 1994;151(1):54-61..

5. Neijenhuijs KI, Holtmaat K, Aaronson NK, Holzner B, Terwee CB, Cuijpers $\mathrm{P}$, et al. The International Index of Erectile Function (IIEF) - A Systematic Review of Measurement Properties. J Sex Med 2019;16(7):1078-91.

6. Rini PS, Apriany A, Romadoni S. Hubungan antara Usia dan lama menderita DM dengan kejadian disfungsi ereksi pada pasien diabetes melitus. Babul Ilmi: Jurnal Ilmiah Multi Science Kesehatan 2019;11(1):196-205.

7. Yassin AA, Nettleship JE, Almehmadi Y, Yassin DJ, El Douaihy Y, Saad F. Is there a relationship between the severity of erectile dysfunction and the comorbidity profile in men with late onset hypogonadism? Arab J Urol 2015;13(3):162-8.

8. Derosa G, Tinelli C, D'Angelo A, Ferrara G, Bonaventura A, Bianchi L, et al. Glyco-metabolic profile among type 2 diabetic patients with erectile dysfunction. Endocr J 2012;59(7): 611-9.

9. Jazayeri M, Kazemi B, Aminsharifi S, Ashraf A, Naseri M, Nasseri A, Vahedi A. Sympathetic Skin Response in Patients with Vascular Erectile Dysfunction. World J Mens Health 2014;32(1): 36-42.

10. Hylmarova S, Stechova K, Pavlinkova G, Peknicova J, Macek M, Kvapil M. The impact of type 1 diabetes mellitus on male sexual functions and sex hormone levels. Endocr J 2020;67(1):59-71.

11. Nutalapati S, Ghagane SC, Nerli RB,
Jali M V., Dixit NS. Association of erectile dysfunction and type II diabetes mellitus at a tertiary care centre of south India. Diabetes Metab Syndr Clin Res Rev 2020;14(4):649-53.

12. Derosa G, Romano D, Tinelli C, D'Angelo A, Maffioli P. Prevalence and associations of erectile dysfunction in a sample of Italian males with type 2 diabetes. Diabetes Res Clin Pract 2015;108 (2):329-35.

13. Cander S, Coban S, Altuner S, Oz Gul O, Yetgin ZA, Akkurt A, et al. Prevalence and correlates of erectile dysfunction in type 2 diabetes mellitus: A crosssectional single-center study among Turkish patients. Metab Syndr Relat Disord 2014;12(6): 324-9.

14. Maiorino MI, Bellastella G, Della Volpe E, Casciano O, Scappaticcio L, Cirillo P, et al. Erectile dysfunction in young men with type 1 diabetes. Int $\mathbf{J}$ Impot Res 2017;29(1):17-22.

15. Nisahan B, Kumanan T, Rajeshkannan N, Peranantharajah T, Aravinthan M. Erectile dysfunction and associated factors among men with diabetes mellitus from a tertiary diabetic center in Northern Sri Lanka. BMC Res Notes 2019;12(1):4-9.

16. Gotera W, Widhyasa, Suastika K, Saraswati MR. Relationship between Erectile Dysfunction and HbA1C Percentage in Diabetic Patients at Sanglah Hospital, Bali, Indonesia. Int J Sci Res 2017; 6(9):1200-1.

17. Corona G, Rastrelli G, Balercia G, Lotti F, Sforza A, Monami M, et al. Hormonal Association and Sexual Dysfunction in Patients with Impaired Fasting Glucose: A Cross-Sectional and Longitudinal Study. J Sex Med 2012;9(6): 1669-80. 
18. Xia JD, Han YF, Zhou LH, Xu ZP, Chen Y, Dai YT. Sympathetic skin response in patients with primary premature ejaculation. Int J Impot Res 2014;26(1):31-4.

19. Yu Y, Hu L, Xu Y, Wu S, Chen Y, Zou $\mathrm{W}$, et al. Impact of blood glucose control on sympathetic and vagus nerve functional status in patients with type 2 diabetes mellitus. Acta Diabetol 2020;57(2):141-50.

20. Sanavi S, Ghods A, Afshar R. of Kidney Diseases and Transplantation Original Article Catheter associated infections in hemodialysis patients. Transplantation 2007;18(1):43-6.

21. Ibrahim I, Oenzil F, Amir A. Hubungan Obesitas dengan Hormon Testosteron pada Mahasiswa STIKes Indonesia Padang. Jurnal Kesehatan Andalas 2015;4(3): 772-6.

22. Maratni NPT. Hubungan Sindrom Metabolik Dengan Kejadian Disfungsi Ereksi Pada Pasien Pria Diabetes Melitus Tipe 2 di Poliklinik Penyakit Dalam RSUP Sanglah Denpasar. E-Jurnal Medika Udayana 2016;5(3):1-13. 